\title{
帰還雷撃に伴う電磁界波形の特徵の再現
}

\author{
学生員 宮㟝 悟* 正員 石井 勝* \\ 正 員 馬場 吉弘**
}

\section{Reproduction of Features of Electromagnetic Field Waveforms Associated with Lightning Return Stroke}

Satoru Miyazaki*, Student Member, Masaru Ishii*, Member, Yoshihiro Baba**, Member

A lightning return stroke model is indispensable in calculating electromagnetic field associated with a return stroke. A lot of return stroke models have been proposed, however, no model has ever succeeded in reproducing all the features of typical electromagnetic field waveforms at various distances. In this paper, two return stroke models are proposed. One is a Transmission-Line type model, and the other is modification of Diendorfer-Uman model. These models successfully reproduce all the features of typical electromagnetic field observed on ground.

キーワード : 雷 , 帰還雷撃モデル , LEMP

Keywords: lighting, return stroke model, LEMP

1. はじめに

帰還雷撃モデルは，雷放電路上の電流と光れに伴う電磁 界変化を結びつけるものであり, 配電線や通信線の故障の 原因となる誘導雷の解析 ${ }^{(1)}$ や落雷位置標定システムにおけ る電流波高值の推定 ${ }^{(2)}$ にも用いられている。Rakov らは帰 還雷撃モデルを物理モデル，分布定数回路モデル，電磁界 モデル, 工学モデルに分類している(3)。この中で工学モデ ルは, 任意の位置 (高さ) における電流波を地表での電流 波形に関連付けた簡単な式で表現したものであり，帰還雷 撃電流の波高値推定や誘導雷解析に広く用いられているの みでなく，雷放電路の構造解明という目的にとっても有用 なモデルである。工学モデルは, 帰還雷撃に伴う典型的な 電磁界波形の特徵を再現するか否か調べることで評価が行 われてきた ${ }^{(4)(5)}$ 。帰還雷撃に伴う全ての電磁界波形の特徵 を再現することは，工学モデルにおける大きな目標となっ ている。しかし，弚のようなモデルは未だ提案されていな い(4)(5)。本論文では, 帰還雷撃に伴う典型的な電磁界波形の 全ての特徵を再現する工学モデルを 2 種提案する。

\footnotetext{
* 東京大学生産技術研究所

干 155-8505 東京都目黑区駒場 4-6-1

Institute of Industrial Science, University of Tokyo

4-6-1, Komaba, Meguro-ku, Tokyo 153-8505

** 同志社大学工学部

厂 610-0321 京田辺市多々羅都谷 1-3

Faculty of Engineering, Doshisha University

1-3, Miyakodani, Tatara, Kyotanabe 610-0321
}

\section{2. 従来の工学モデル}

工学モデルを用いた電磁界計算では，一般に図 1 に示す ような垂直な雷放電路を仮定する。位置 (高さ) $z$ の微小 区間 $d z$ を流れる電流 $i(z, t)$ によって発生する電磁界は, 大 地か完全導体平面であると仮定して (1)，(2) 式を用いて計 算できる ${ }^{(6)}$ 。

$$
d B_{\phi}=\frac{\mu_{0}}{2 \pi}\left[\frac{\sin \theta}{r^{2}} i(z, t-r / c)+\frac{\sin \theta}{c r} \frac{\partial i(z, t-r / c)}{\partial t}\right] d z
$$

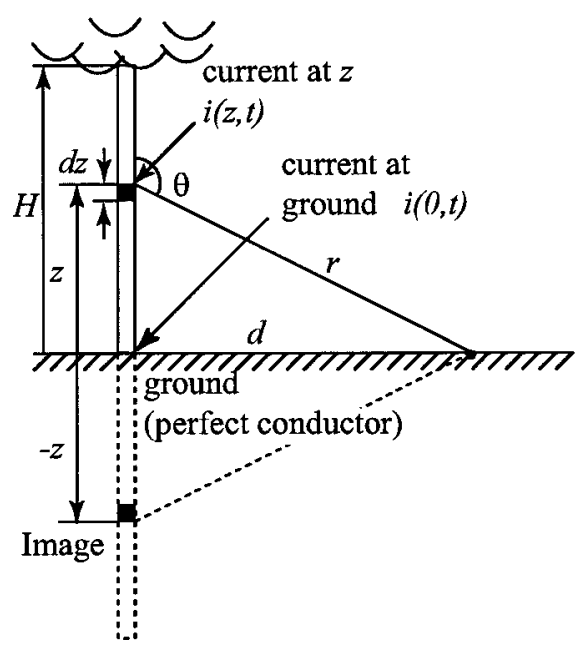

図 1 幾何学的位置関係

Fig. 1. Geometry of the system. 


$$
\begin{aligned}
d E_{z}= & \frac{1}{2 \pi \epsilon_{0}}\left[\frac{2-3 \sin ^{2} \theta}{r^{3}} \int_{0}^{t} i(z, \tau-r / c) d \tau\right. \\
& +\frac{2-3 \sin ^{2} \theta}{c r^{2}} i(z, t-r / c) \\
& \left.-\frac{\sin ^{2} \theta}{c^{2} r} \frac{\partial i(z, t-r / c)}{\partial t}\right] d z \ldots \ldots \ldots \ldots
\end{aligned}
$$

ここで, $r$ は微小区間と電磁界観測点の距離,$\theta$ は 観測点と微小区間を結ぶベクトルが鉛直方向に対 しなす角， $\epsilon_{0}$ は真空の誘電率， $\mu_{0}$ は真空の透磁率， $c$ は光速である。

現在までに提案されている工学モデルは , 伝送線路型モ デルと放電型モデルに大別される ${ }^{(3)}$ 。とれらの概念図を図 2 に示す。伝送線路型モデルは,地表に電流源を置き, 電流波 が上方へ伝搬していくモデルである。電流波の伝搬過程に おいて, 減衰も変歪もせず伝搬するモデルが伝送線路 (TL) モデル ${ }^{(6)}$ である。TL モデルは，伝搬に伴う減衰および変 歪を考慮して樣々な改良が加えられている ${ }^{(5)(7)}$ 。一方, 放電 型モデルは, リーダに蓄積されていた電荷が雷放電路の地 上端から上昇する帰還雷撃電流波の波面の到達と共に拘束

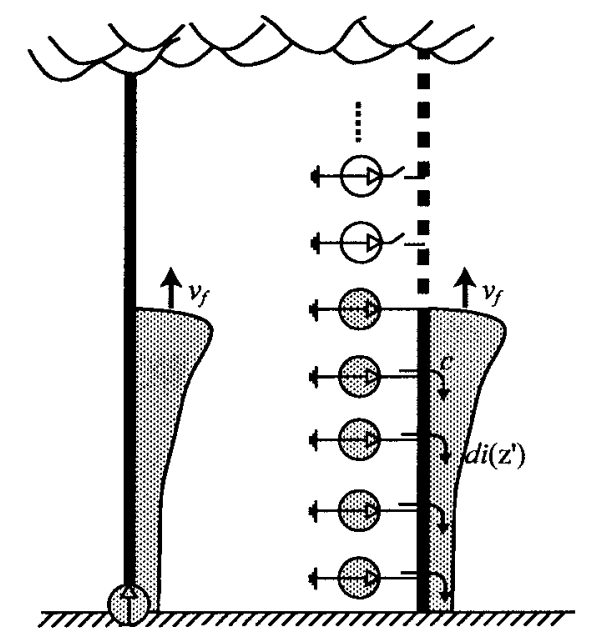

Transmission-Line type Discharge-type

図 2 伝送線路型モデルと放電型モデルの概念図

Fig. 2. Schematic illustration of TL-type and dischargetype model.
を解かれ, 光速で下向きに移動し電流となるモデルである。 TCS モデル ${ }^{(8)}$ では帰還雷撃の到達と共に遅滞無く電荷が拘 束を解かれる。また DU モデル ${ }^{(9)}$ では, 帰還雷撃の到達と 共に遅れ時間をもって電荷が拘束を解かれる。各種モデル の特徵と電流波の数式的表現をまとめたものを表 1 に示す。

工学モデルに対する評価は, 典型的な帰還雷撃電流波形 を入力としたときに, 観測されている典型的な電磁界波形 の主要な特徵を再現できるか調べることによって行われて いる ${ }^{(4)(5)}$ 。評価に用いられる典型的な電磁界波形の特徵と しては, Lin らによる自然雷後続雷撃に伴う電磁界多地点 同時観測結果 ${ }^{(10)}$ (図 3(a)〜(c)) より, 以下の 4 つが挙げら れている。

（1）電界，磁界ともに鋭い初期ピークがある $(1 \mathrm{~km}$ 程度以遠ではピークの大きさは距離に反比例する) (図 3(a), (b), (c))。

(2) 数 $\mathrm{km}$ の距離の電界が初期ピーク後 $100 \mu \mathrm{s}$ 程度の 間直線的に増加する (図 3(a))。

(3) 数 $\mathrm{km}$ の距離の磁界が初期ピーク後緩やかなピー ク (hump) をもつ (図 3(b))。

(4) 50〜200 km の距離の電磁界が初期ピークの後数十 $\mu \mathrm{s}$ でゼロレベルを横切る (図 3(c))。

また，近年のロケット誘雷技術を用いた観測により，雷

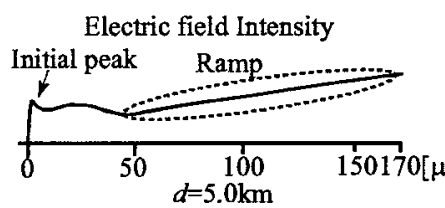

(a)

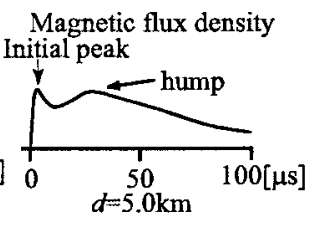

(b)

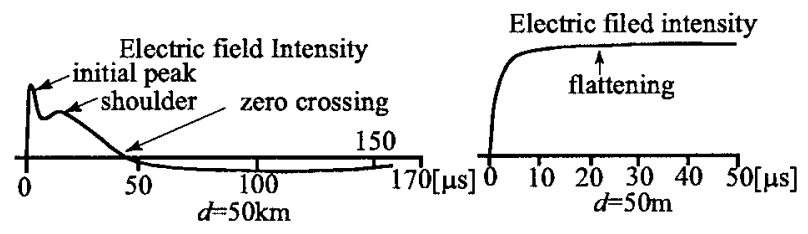

(c)

(d)

図 3 後続帰還雷撃に伴う典型的な電磁界波形 ${ }^{(10)(11)}$

Fig. 3. Typical electromagnetic field waveforms associated with subsequent lightning return strokes ${ }^{(10)(11)}$.

\begin{tabular}{|c|c|c|c|}
\hline Category & Model & Features & Mathematical representation \\
\hline \multirow{4}{*}{$\begin{array}{c}\text { Transmission } \\
\text { Line type }\end{array}$} & $\mathrm{TL}^{(6)}$ & No decay or distortion. & $i(z, t)=i\left(0, t-z / v_{f}\right)$ \\
\hline & $\operatorname{MTLL}^{(7)}$ & Linear decay with height & $i(z, t)=i\left(0, t-z / v_{f}\right) \times(1-z / H)$ \\
\hline & $\operatorname{MTLE}^{(7)}$ & Exponential decay with height & $i(z, t)=i\left(0, t-z / v_{f}\right) \times \exp (-z / \lambda)$ \\
\hline & $\operatorname{MTLD}^{(5)}$ & Decay and distortion with height & $i(z, t)=i\left(0, t-z / v_{f}\right)\left[1-\exp \left(\frac{t-z / v_{f}}{\tau} \frac{\lambda p}{z}\right)\right]\left(1-\frac{z}{H_{p}}\right)$ \\
\hline \multirow[t]{2}{*}{ Discharge type } & $\operatorname{TCS}^{(8)}$ & Charge flows into channel instantly & $i(z, t)=i(0, t+z / c)$ \\
\hline & $\mathrm{DU}^{(9)}$ & Charge flows into channel with delay & $i(z, t)=i(0, t+z / c)-i\left(0, z / v_{f}+z / c\right) \times \exp \left(-\frac{t-z / v_{f}}{\tau_{d}}\right)$ \\
\hline
\end{tabular}

表 1 各種工学モデルの特徵と数式的表現

Table 1. Summary of features and mathematical representation for some return stroke models.

$z$ is coordinate along the channel, $t$ is time, $v_{f}$ is return stroke propagation speed, $H$ is a parameter for MTLL model represents linear current decay, $\lambda$ is a parameter for MTLE model represents exponential current decay, $\lambda_{p}$ is a parameter for MTLD model represents current distortion, $H_{p}$ is a parameter for MTLD model represents linear decay, $\tau$ is a time constant for MTLD model, $c$ is speed of light, and $\tau_{d}$ is a discharge time constant for DU model. 


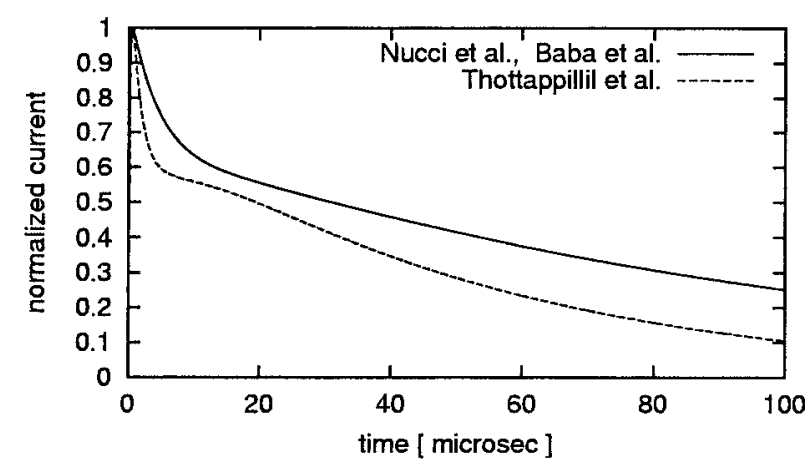

図 4 工学モデルの評価に用いられた電流波形 ${ }^{(4)(5)(13)}$

Fig. 4. Assumed channel-base current waveforms for validation of engineering models ${ }^{(4)(5)(13)}$.

\section{表 2 各モデルによる後続雷撃に伴う電磁界波形 の特徵の再現性の良否 ${ }^{(4)(5)}$}

Table 2. Ability of six models to reproduce major features of typical electromagnetic field associated with subsequent return stroke ${ }^{(4)(5)}$.

\begin{tabular}{|c|l||c||c|c|c||c|}
\hline \multicolumn{2}{|c||}{} & \multicolumn{3}{c|}{ Near- } & \multicolumn{3}{c|}{ Far } \\
\hline \multicolumn{2}{|c||}{ Feature } & $(5)$ & $(1)$ & $(2)$ & $(3)$ & $(4)$ \\
\hline \multicolumn{2}{|c||}{ distance } & 50 & 5 & 5 & 5 & 100 \\
\multicolumn{2}{|c||}{} & $\times$ & $\mathrm{km}$ & $\mathrm{km}$ & $\mathrm{km}$ \\
\hline \hline Transmission & TL $^{(6)}$ & $\times$ & $\bigcirc$ & $\times$ & $\bigcirc$ & $\times$ \\
Line & MTLL $^{(7)}$ & $\bigcirc$ & $\bigcirc$ & $\bigcirc$ & $\times$ & $\bigcirc$ \\
Type & MTLE $^{(7)}$ & $\times$ & $\bigcirc$ & $\bigcirc$ & $\times$ & $\bigcirc$ \\
& MTLD $^{(5)}$ & $\bigcirc$ & $\bigcirc$ & $\bigcirc$ & $\times$ & $\bigcirc$ \\
\hline \hline Discharge & TCS $^{(8)}$ & $\bigcirc$ & $\bigcirc$ & $\bigcirc$ & $\bigcirc$ & $\times$ \\
type & DU $^{(9)}$ & $\bigcirc$ & $\bigcirc$ & $\bigcirc$ & $\bigcirc$ & $\times$ \\
\hline
\end{tabular}

撃点から至近距離の電界において, 次の特徴が報告されて いる(11)。

（５）５0〜100 m の距離で観測された電界には，平坦と なる時間帯がある (図 3(d))。

Nucci ら ${ }^{(4)}$, Baba ら ${ }^{(5)}$ は, 图 4 に示すような電流波形を 入力とし，各モデルを用いて計算された電磁界が上記 $5 つ$ の特徵を満足するかどうか検討した。電流波形は, Heidler 関数 ${ }^{(8)}$ と二重指数関数の和として表され, Berger ${ }^{(12)}$ らがス イスの高構造物雷撃で観測した後続雷撃の平均的な波形を 模擬したものである。これらの検討結果をまとめたものを， 表 2 に示す。表 2 は, Nucci ら，Baba らの検討結果を，雷 撃点からの距離が近い順に並べている。TCS および DU モ デルは, 遠方電磁界がゼロレベルを切る特徴のみを再現し ていないが, Thottappillil らは, Nucci らおよびBaba らが 用いた電流波形と僅かに異なる電流波形 (图 4) を入力とし た時，TCS およびDU モデルがこの特徴も再現することを 示している ${ }^{(13)}$ 。しかし，入力電流波形の微細な差異によら ず全ての特徵を再現するモデルは未だ提案されていない。

\section{3. 提案モデル}

〈3. 1〉 雷放電路上の電流分布の検討 表 2 上り, 雷 撃点に近い距離における電磁界波形の特徵は放電型モデル
が, 雷撃点から遠い距離における電磁界波形の特徵は伝送 線路型モデルが良く再現していることがわかる。雷放電路 上の微小区間 $d z$ を流れる電流によって発生する電磁界は， (1)，(2) 式に示されるように電磁界観測点までの距離にと もなって減衰する。雷撃点近傍では, 雷放電路上部までの 距離が下部までの距離に比べて十分大きいので, 雷放電路 上部の電流による電磁界への寄与はほとんど無く，雷放電 路下部を流れる電流によって電磁界が決定されると考えら れる。一方遠方では, 雷放電路上部までの距離は下部まで の距離とあまり変わらないため, 電磁界は上部を流れる電 流の影響も受ける。従って, 実際の雷放電路上の電流分布 は，下部では雷撃点近傍の電磁界波形の特徵をよく再現す る放電型モデルに似ており，上部では遠方電磁界の特徵を よく再現する伝送線路型モデルに似ていると考えられる。

図 5 に,各種モデルにおける電流波の波高值と 0-100\%立 ち上がり時間の雷放電路上の位置に伴う変化を示す。この 時各種パラメータは, Nucci ら, Baba らが用いた值と同じ ものを用いた ${ }^{(4)(5)}$ 。放電型 (DU) モデルでは雷放電路下部 で急激に電流波が減衰し，同時に急激に立ち上がり時間が 増加 (变歪) している。他方, 雷放電路上部において伝送 線路型 (MTLL , MTLE , MTLD) モデルは放電型モデル より減衰が大きい。

以上の検討により，雷放電路下部で電流波が急激に減衰 および変歪し, 雷放電路上部でも大きな減衰を続けるモデ ルは, 帰還雷撃に伴う典型的な電磁界波形の特徵を再現す ると考えられる。关の例として MTLD モデルのパラメー タを変更した伝送線路型モデルと，DU モデルを改良した 放電型モデルを提案する。

〈3. 2〉 MTLD モデルのパラメータの変更伝送線路 型モデルを, 雷放電路下部で電流波が急激に減衰および変 歪するよう改良することを考える。伝送線路型モデルの中 で, 電流波の変歪を考慮するモデルは唯一MTLD モデルの みである。MTLD モデルは, 電流波高値の線形な減衰と立 ち上がり時間の線形な増加をほぼ独立に定めることができ るモデルで, 電流波が $\lambda_{p}$ だけ伝搬すると電流波の立ち上が り時間がほぼ $0.7 \mu \mathrm{s}$ 増加する。文献 (5) で用いられている $\lambda_{p}=1000 \mathrm{~m}$ では, 雷放電路下部で電流波形がほとんど変 歪せず，放電型モデルとはかけ離れる。乥こで, 提案モデ ルでは雷放電路下部での变歪を大きくするために $\lambda_{p}$ を極 端に小さくする。この急激な变歪によって, 電流波の波頭 部分がなくなることから，同時に雷放電路下部での急激な 電流波の減衰も実現される。このモデルは, 文献(5) のパ ラメータを用いたモデル (MTLD1) に対して MTLD2 とし て参照する。MTLD2 においては, 雷放電路下部での急激 な電流波の減衰と变歪を実現するために $\lambda_{p}=50 \mathrm{~m}$ とした。 $H_{p}$ は，文献(5) と同じ $9000 \mathrm{~m}$ とした。図 6 に，MTLD2 モデルの電流波高値と立ち上がり時間の雷放電路上の位置 による変化を示す。

〈 3. 3〉DU モデルの改良＼cjkstart放電型モデルである DU モ デルを雷放電路上部でも電流波が減衰を続けるよう改良す 


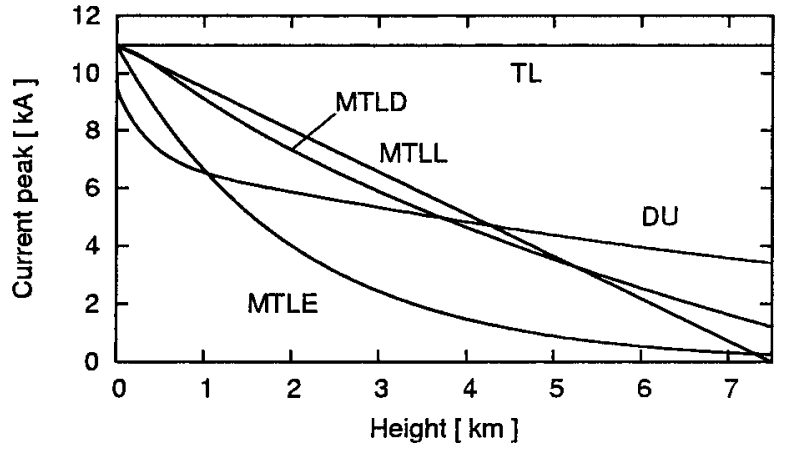

(a) Current peak (0-7.5 km range)

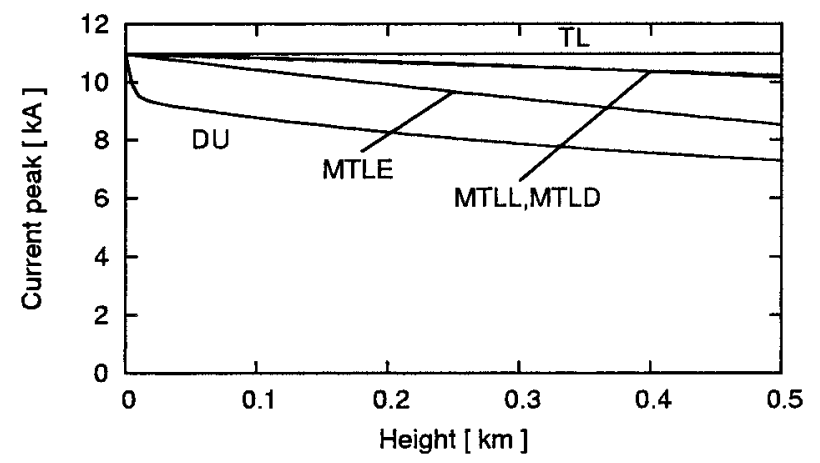

(b) Current peak (0-0.5 km range)

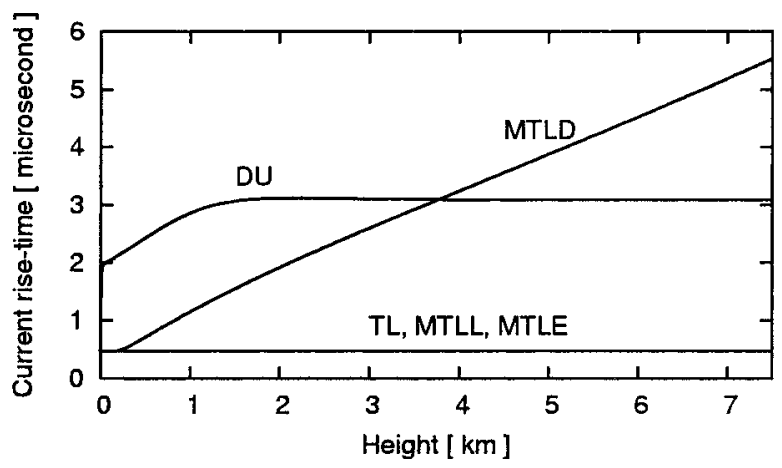

(c) $0-100 \%$ current rise-time $(0-7.5 \mathrm{~km}$ range $)$

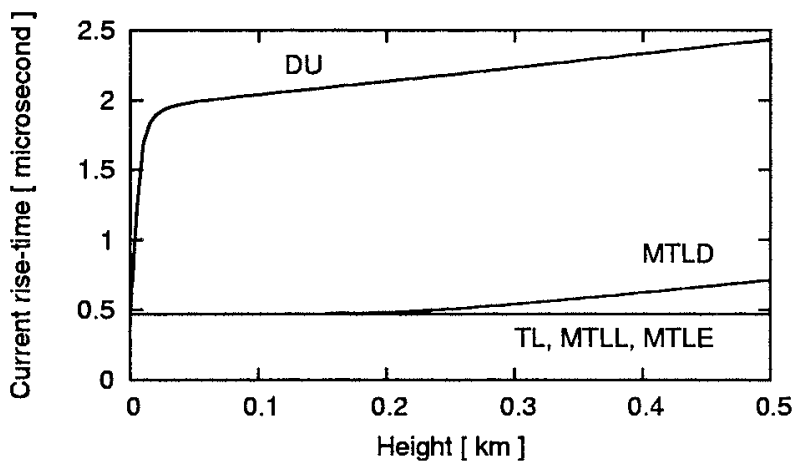

(d) $0-100 \%$ current rise-time $(0-0.5 \mathrm{~km}$ range)

図 5 各モデルにおける電流波高値，0-100\% 立ち上がり時間の雷放電路上の位置による変化 Fig. 5. Variation of current peak and $0-100 \%$ current rise-time dependent on height for each model.

る。このことは DU モデルに雷放電路下部では減衰せず， 雷放電路上部で咸衰するような項を加えることで実現でき る。提案モデルの要求は，例えば (3) 式で実現できる。

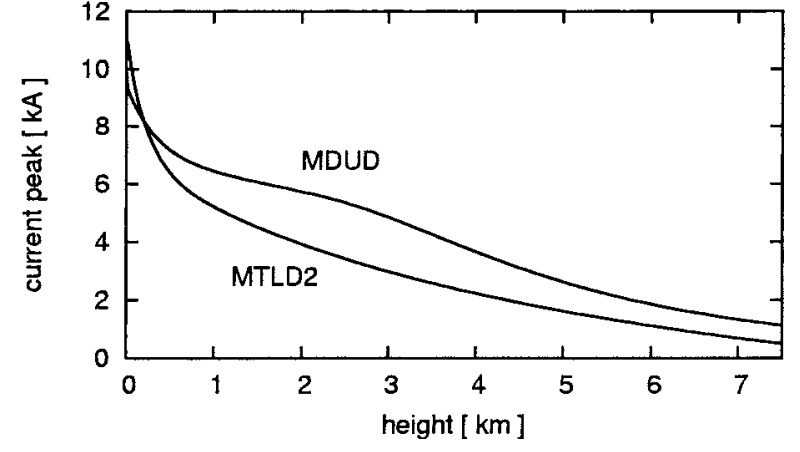

(a) Current peak (0-7.5 km range)

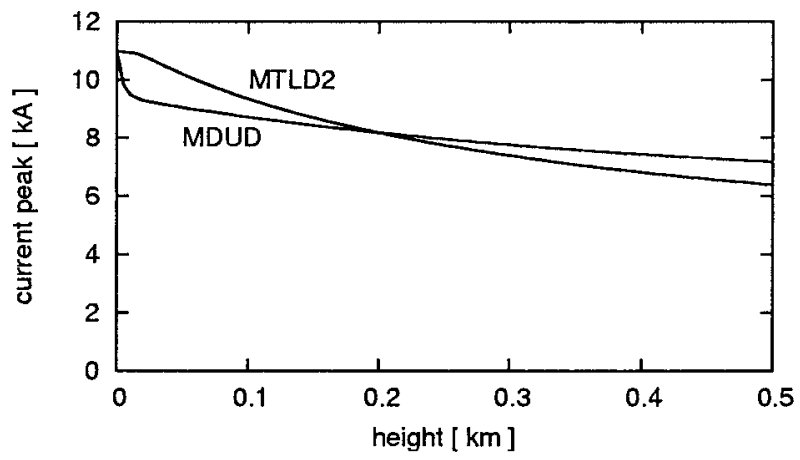

(b) Current peak $(0-0.5 \mathrm{~km}$ range)

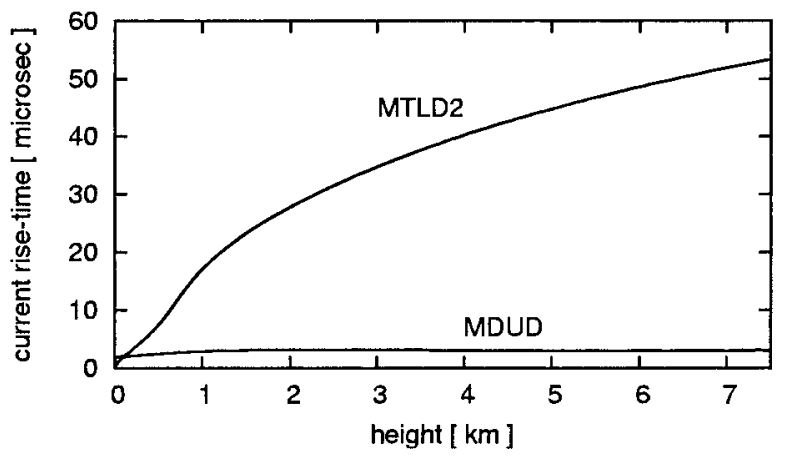

(c) $0-100 \%$ current rise-time $(0-7.5 \mathrm{~km}$ range)

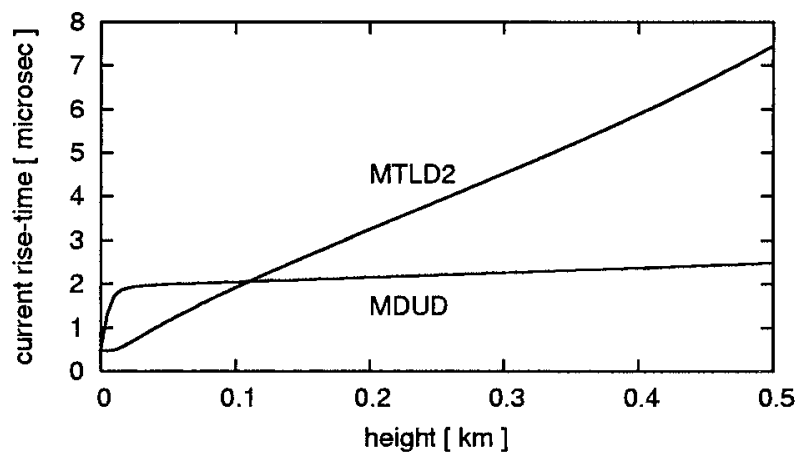

(d) $0-100 \%$ current rise-time $(0-0.5 \mathrm{~km}$ range)

図 6 提案モデルにおける電流波高值，0-100\% 立ち上がり時間の雷放電路上の位置による変化 Fig. 6. Variation of current peak and $0-100 \%$ current rise-time dependent on height for proposed models.

$i(z, t)=i_{D U}(z, t) \times\left[1-\exp \left\{-\left(\frac{\lambda_{d}}{z}\right)^{n}\right\}\right]$

ここで, $i_{D U}(z, t)$ は DU モデルにおける電流,$\lambda_{d}$ 
は減衰を表す定数, $n$ は定数である。

このモデルは以降 , Modified DU model with additional Decay (MDUD) とする。MDUD モデルにおいて，雷放電路 下部での減衰が大きくなりすぎて他の電磁界波形の特徵を

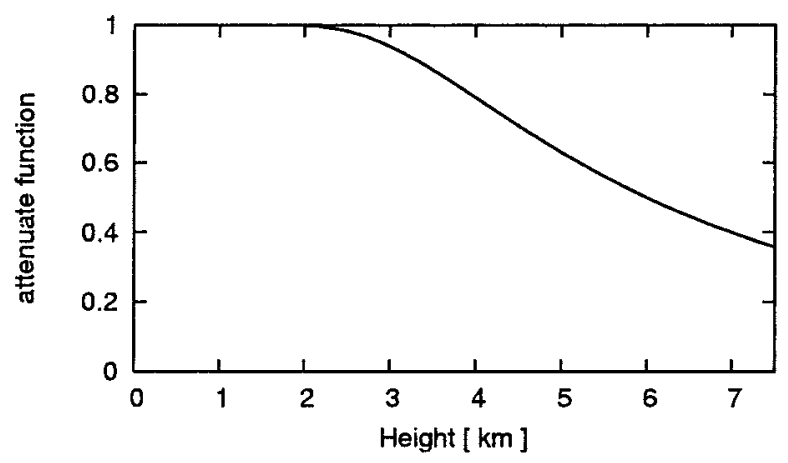

図 7 MDUD モデルにおいて付加された減衰関数

Fig. 7. Attenuation function for MDUD model.
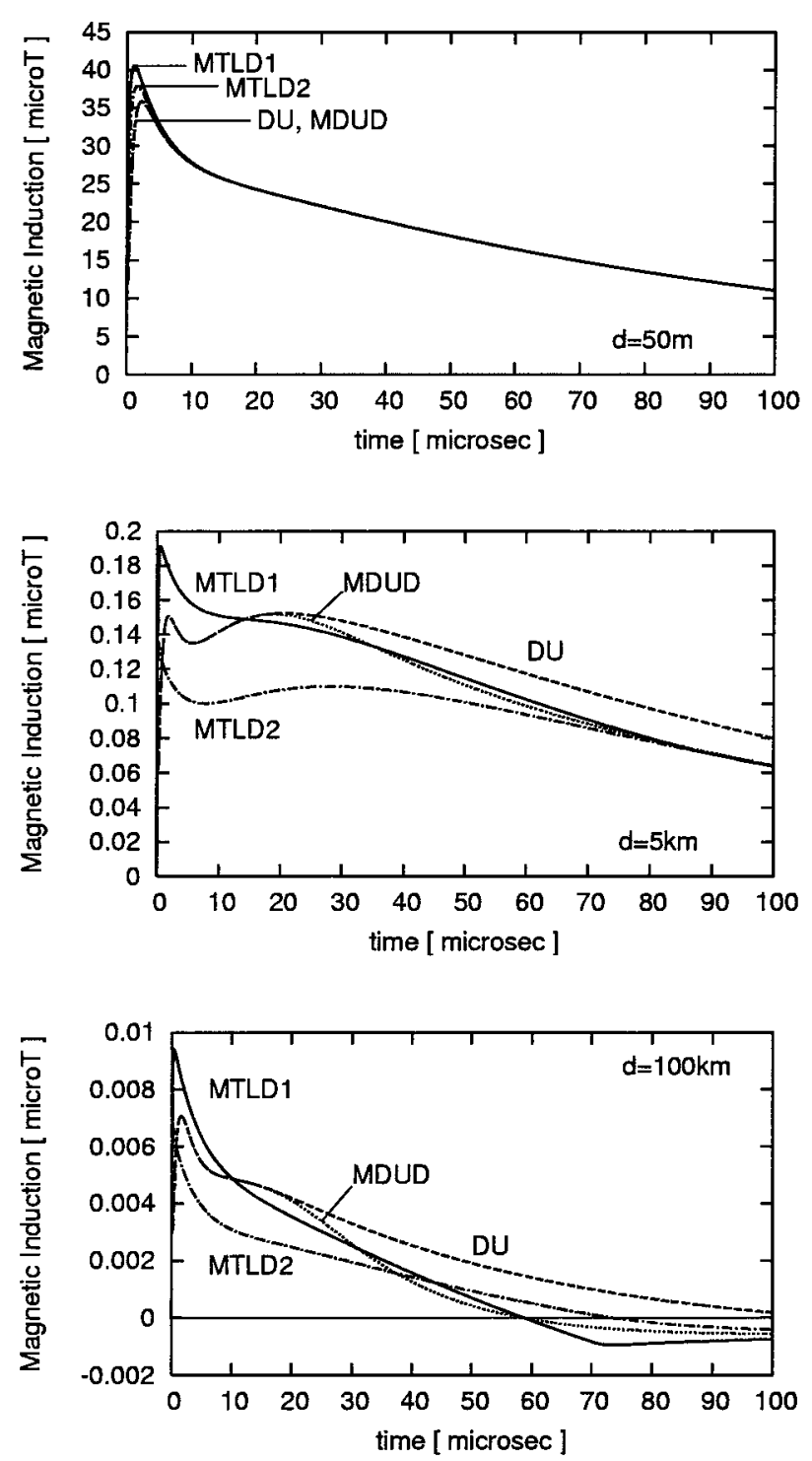

図 8 提案モデルを用いて計算された $50 \mathrm{~m}, 5 \mathrm{~km}, 100 \mathrm{~km}$ 地点における電磁界波形

Fig. 8. Calculated electromagnetic field waveforms at $50 \mathrm{~m}, 5 \mathrm{~km}$, and $100 \mathrm{~km}$, using proposed models.

再現できなくなることがないように $\lambda_{d}=5000 \mathrm{~m}$ および $n=2$ とした。このときの減衰関数を图 7 に示す。また， 図 6 にMDUD モデルの電流波高值と立ち上がり時間の雷 放電路上の位置による変化を示す。MDUD モデルの電流 波高值は高さ $2 \mathrm{~km}$ 付近でやや不自然な変化をしているが， これは単に提案モデルの減衰項を簡単な関数形で表現しよ うとしたためで重要ではない。

\section{4. 電磁界計算結果および検討}

以上の提案モデルと，MTLD1 およびDU モデルを用い て計算された $d=50 \mathrm{~m}, 5 \mathrm{~km}, 100 \mathrm{~km}$ における電磁界波 形を图 8 に示す。提案モデルのパラメータは前節で示した ものを用いた。また，帰還雷撃は一定速度 $v_{f}$ で上方に伝搬 するものとし，光の速度は Nucci ら ${ }^{(4)}, \mathrm{Baba} ら^{(5)}$ と同樣 に光学観測の結果 ${ }^{(14)}$ から $130 \mathrm{~m} / \mu \mathrm{s}$ とした。提案した 2 種 のモデルは，いずれも典型的な帰還雷撃に伴う電磁界波形 の全ての主要な特徵を再現している。なお, 図 3 の遠方電
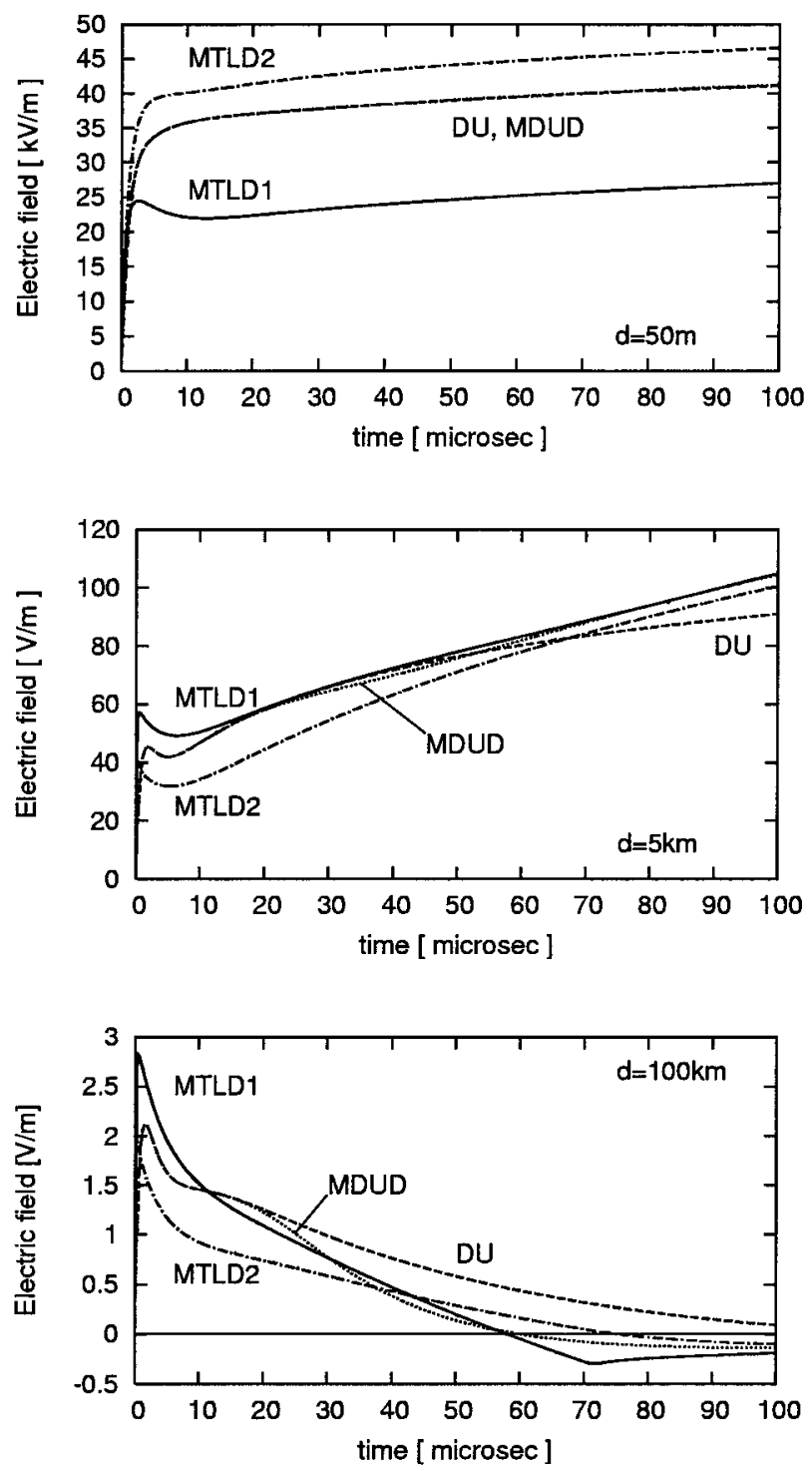
磁界波形例の $20 \mu \mathrm{s}$ 付近に現れている shoulder と呼ばれる 小さなピークは, MDUD モデルでよく再現されており，こ の特徵と電流分布の関係に手がかりを与えている。なお， shoulder はいつも実測波形に顕著に現れるわけではない。

図 6 に示したように,両提案モデルは,雷放電路下部で急 激に電流波が減衰およひ变歪し, 雷放電路上部でも引き続 きDU モデルより急速に減衰を続ける。しかし，立ち上が り時間は雷放電路上部になるほど両モデルで大きく異なっ ている。この雷放電路上部の立ち上がり時間は, 地上で観 測される電磁界波形の特徽にはあまり影響しない。

DU モデルを雷放電路上部で電流波が減衰を続けるよう 改良することで，DU モデルの弱点であった遠方電磁界波 形がゼロレベルを切る特徵が再現された。このことからこ の特徵は, 雷放電路上部で電流波が DU モデルよりも大き く減衰していることを示唆している。

TCS モデルを仮定すると，位置 $z$ に蓄積されていた電荷 が移動することによる電流は, 帰還雷撃開始から帰還雷撃 電流波面が $z$ だけ進む時間 $\left(z / v_{f}\right)$ と電荷か地表に達する までの時間 $(z / c)$ だけ遅れて地表て観測されるので, 地表 における電流には, 時刻 $t=z / v_{f}+z / c$ に反映される。従っ て, 雷放電路上の位置 $z$ における電流波高値は, この時刻 の地表の電流值によって決定される。DU モデルもほぼ同 樣である。従って放電型モデルでは，地表での電流波の波 尾長が短い場合，雷放電路上部での電流波高值は小さくな る。すなわち雷放電路上部で大きく減衰する。Thottappillil ら ${ }^{(13)}$ はこの性質を利用し，波尾の短い電流波形を入力とし て，放電型モデルでも遠方電磁界がゼロレベルを切る特徵 を再現できることを示した。しかし，Bergerら ${ }^{(12)}$ の観測結 果では, 約 75\%の後続雷撃電流の波尾長は Thottappillil ら が用いた $20 \mu \mathrm{s}$ よりも長い。今回提案したモデルは，標準 的な波尾長 $32 \mu \mathrm{s}$ の電流波形に対して, 遠方電磁界がゼロ レベルを切る特徵を再現できる。

提案モデルでは,帰還雷撃速度を一定とした。しかし, 文 献 (14)の観測では, 雲底での帰還雷撃速度は雷放電路最下 部より $25 \%$ 程遅くなっている。〈3・1 節の検討から，兴の 雷放電路近傍の電磁界波形への影響は小さく，遠方の電磁 界で, 帰還雷撃か雷放電路の上部に達した後の波尾部分へ 影響することがわかる。しかし，観測された程度の速度变 化では, 電磁界がゼロレベルを切る時間が少し早くなる程 度で, 帰還雷撃速度を一定としても，本論文で檢討した電 磁界波形の再現性に関しては影響しない。

地上での雷電流と発光強度波形はピークまではよく一致 し，地上の雷電流波高值と光れに伴う発光強度ピーク值の 間には比例関係があるが, 弚の後は発光強度のほうが早く 減衰することか報告されている ${ }^{(15)}$ このことから，雷放電 路上部では電流波の立ち上がり時間が長くなるにしたがい， 雷電流と発光強度のピークが比例しなくなる可能性がある。 比較可能な雷放電路下部 $100 \mathrm{~m}$ 程の領域においては, 提案 モデルの電流波高値および立ち上がり時間の高度変化は， 発光強度のピーク值と立ち上がり時間の変化の実測 ${ }^{(16)}$ と概
ね一致する。

\section{5. まとめ}

本論文では, 工学モデルの一つの大きな目標になってい る, 帰還雷撃に伴い地表で観測される典型的な電磁界波形 の全ての特徵を, 電流波の減衰と变歪を定量的に考慮した 帰還雷撃モデルで再現できることを示した。計算される電 磁界波形を典型的な観測波形と比較することにより，雷放 電路下部数百 $\mathrm{m}$ では電流波が急激に減衰, 変歪し, 上部で も緩やかに減衰を続けると推論される。このことから，雷 放電路下部での急激な電流波の減衰と变歪を含む伝送線路 型モデル，電流波が雷放電路上部においても減衰する放電 型モデルの 2 種を新たに提案し，観測される電磁界波形の 全ての特徵を再現できることを確認した。雷放電路下部で のモデル上の電流波の減衰, 变歪の樣相は, 発光強度から 推測される電流波の減衰，变歪とおおむね一致する。 (平成 16 年 7 月 23 日受付, 平成 16 年 11 月 22 日再受付)

\section{文献}

(1) K. Michishita and M. Ishii: "Analysis of Observed Lightning-Induced Voltage by Taking Account of Horizontal E-Field", T. IEE Japan, Vol.120-B, No.10, pp.1304-1308 (2000-10) (in Japanese)

道下幸志・石井 勝 : 「実雷撃に伴って観測された誘導電圧の水平 電界を考慮した解析」, 電学論 B, 120, 10, pp.1304-1308 (2000-10)

( 2 ) V.P. Idone, A.B. Saljoughy, R.W. Henderson, P.K. Moore, and R.B. Pyle: "A Reexamination of the Peak Current Calibration of the National Lightning Detection Network", J. Geophys. Res., Vol.98, No.D10, pp.18323-18332, (1993-10)

( 3 ) V.A. Rakov and M.A. Uman: "Review and Evaluation of Lightning Return Stroke Models Including Some Aspects of Their Application", IEEE Trans. Electromag. Compatibility, Vol.40, No.4, pp.403-426 (1998-11)

(4) C.A. Nucci, G. Diendorfer, M.A. Uman, F. Rachidi, M. Ianoz, and C. Mazzetti: "Lightning Return Stroke Current Models with Specified Channel-Base Current: A Review and Comparison", J. Geophys. Res., Vol.95, No.D12, pp.20395-20408 (1990-11)

( 5 ) Y. Baba and M. Ishii: "Lightning Return Stroke Model Incorporating Current Distortion”, IEEE Trans. Electromag. Compatibility, Vol.44, No.3, pp.476-478 (2002-8)

( 6 ) M.A. Uman, D.K. McLain, and E.P. Krider: "The Electromagnetic Radiation from Finite Antenna", Ame. J. Phys., Vol.43, pp.33-38 (1975-1)

( 7 ) V.A. Rakov and A.A. Dulzon: "A Modified Transmission Line Models for Lightning Return Stroke Field Calculation”, Proc. 9th Int. Symp. EMC, pp.229-235, Zurich, Switzerland (1991)

( 8 ) F. Heidler: "Traveling current source model for LEMP calculation", Proc. 6th Int. Zurich Symp. Electromagnetic Compatibility, pp.157-162, Zurich, Switzerland (1985-3)

(9) G. Diendorfer and M.A. Uman: "An Improved Return Stroke Model with Specified Channel Base Current", J. Geophys. Res., Vol.95, No.D9, pp.13621-13644 (1990-8)

(10) Y.T. Lin, M.A. Uman, J.A. Tiller, R.D. Brantley, W.H. Beasley, E.P. Krider, and C.D. Weidman: "Characterization of Lightning Return Stroke Electric and Magnetic Fields from Simultaneous Two-Station Measurements", J. Geophys. Res., Vol.84, No. pp.6307-6314 (1979-10)

(11) M.A. Uman, V.A. Rakov, K.J. Rambo, T.W. Vaught, M.I. Fernandez, D.J. Cordier, R.M. Chandler, R. Bernstein, and C. Golden: "Triggered- Lightning Experiments at Camp Blanding, Florida (1993-1995)”, T. IEE Japan, Vol.117-B, No.4, pp.446-452 (1997-4)

(12) K. Berger, R.B. Anderson, and H. Kuroninger: "Parameters of Lightning Flashes", Electra, No.41, pp.22-37 (1977)

(13) R. Thottappillil, M.A. Uman, and G. Diendorfer: "Influence of Channel Base Current and Varying Return Stroke Speed on the Calculated Fields of Three Important Return Stroke Models", Proc. Int. Conf. Lightning Static Electricity, pp.118.1-118.9, Cocoa Beach, FL (1991-4) 
(14) V.P. Idone and R.E. Orville: "Lightning Return Stroke Velocity in the Thunderstorm Research International Program (TRIP)", J. Geophys. Res., Vol.87, No. C7, pp.4903-4915 (1982-6)

(15) D. Wang, N. Takagi, T. Watanabe, V.A. Rakov, M.A. Uman, K.J. Rambo, and M.V. Stapleton: "A comparison of channel-base currents and optical signals for rocket-triggered lightning strokes", Proc. 12th Int. Conf. on Atmospheric Electricity, pp.557-560, Versailles, France (2003-6)

(16) D. Wang, N. Takagi, X. Liu, T. Watanabe, and A. Chihara: "Luminosity Characteristics of Multiple Dart Leader/Return Stroke Sequence Measured With a High-Speed Digital Image System", Geophys. Res. Lett., Vol.31, doi:10.1029/2003GL018613 (2004)

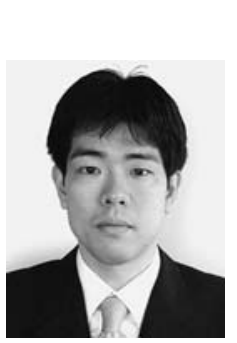

(学生員) 1977 年 8 月 26 日生。2001 年 3 月東 京大学工学部電気工学科卒業。2003 年 3 月東京 大学大学院工学系研究科修士課程修了。同年 4 月 博士課程に進学。現在に至る。雷放電に関する研 究に従事。2003 年度電気学会論文発表賞。
石 井

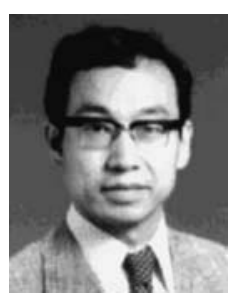

勝 (正員) 1949 年 3 月 11 日生。1976 年 3 月東京 大学大学院博士課程修了。工学博士。同年 4 月東 京大学助教授, 生産技術研究所勤務, 1992 年同教 授,現在に至る。主として,系統絶縁,自然雷,高 電圧現象の測定に関する研究に従事。2004 年よ り電気学会 B 部門長。CIGRE SC C4 国内分科会 委員長。1998 年電気学会進歩賞, 1999 年同論文 賞。IEEE Fellow , AGU Member, CIGRE Member

馬場吉 弘 (正員) 1971 年 2 月 24 日生。1994 年 3 月東京

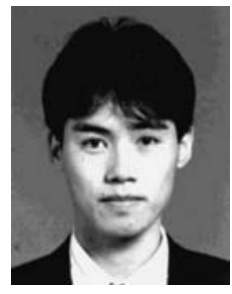
大学工学部電気工学科卒業。1996 年 3 月同大学 大学院工学系研究科電気工学専攻修士課程修了。 1999 年 3 月同専攻博士課程終了。工学博士。同 年 4 月同志社大学助手。2001 年 4 月, 同専任講 師。2003 年〜2004 年フロリダ大学客員研究員。 電磁界パルスに関する研究に従事。1999 年電気 学会論文賞。2002 年度同発表賞。AGU，IEE お 